\section{Geographical Aspect of Tourism in Borderline Municipalities of Vojvodina}

\section{Stankovic, M, Cirkovic, Sanja*}

Abstract Vojvodina as a rather flat and spacious $\left(21506 \mathrm{~km}^{2}\right)$ area stands as the part of Serbia which is situated between Croatia, Hungary, Romania and the rivers Danube and Sava. It is also a part of Pannonic lowland formed by tectonic activities of the part of the Earth's crust. During its morphological evolution Vojvodina passed through ocean, sea and lake phase. Two island mountains overlooking the cultivated land stand as special marks of the landscape and have significance for tourism. The area has been settled long time ago with urban and rural settlements, but still it remains under explored from the archaeological point of view. Some of the settlements are situated in the borderline region with features of joining and interrelating, but also of secession and distancing. The presented material refers to the analysis of participation of borderline municipalities of Vojvodina in several geographic and tourist attractive phenomena and processes. The paper deals with the number of settlements, area, population, and population density, number of catering objects, accommodation and tourist traffic and overnight stays. More precisely, to switch from geography to tourism, borderline municipalities of Vojvodina demand systematic scientific research due to their versatile character.

Key words Vojvodina, borderline municipalities, tourism, material basis, population, settlements, and depopulation
Tourism in Vojvodina has long and

T eventful history. Easily accessible lowland, populated long time ago, with rich agriculture, Vojvodina is recognizable by its significant possibilities for development of various types of tourism. Furthermore, it is characterized by solid network of road, railroad and water traffic lines, as well as numerous settlements (467). Bordered by high mountains, it has always been an attractive residential area. Due to the fact that, in the past, a number of young people from Vojvodina were educated in eminent centers of Europe, cultural influences, habits and needs for tourist travels were demonstrated long time ago. Vojvodina is situated in the basins of several large rivers (Danube, Sava, and Tisa), featured with two island mountains (Fruska gora and Vrsacke planine). Also on its territory there are several natural and artificial lakes (Palic, Ludasa, Rusanda, Zobnatica and Ecka) and several protected nature reserves (Fruska gora, Palic, Ludas, Carska bara, the Upper Danube Basin),

\footnotetext{
* Stevan M. Stankovic, Sanja Cirkovic, University of Belgrade, Faculty of Geography, Studentski trg 3, 11000 Beograd, Serbia and
} Montenegro which altogether help Vojvodina in organizing cultural and sports manifestations.

On the tourist map of Serbia, Vojvodina is recognizable by its offer of gastronomic specialties, and also by numerous antropogenous tourist values and objects, among which those assigned to culture and tourism stand out (Petrovaradin Fortress, Castle Ecka, Castle Dundjerski, and Panonija). From the point of view of tourism, numerous existing border crossings towards neighboring states are also important. They serve for road, railroad and water traffic and enable border regional and international traffic of goods and passengers. Almost all crossings are open 24 hours a day during the whole year (Romelic, et al.,2002).

\section{Border and border crossings}

In the north Vojvodina borders Hungary. The length of the border is $174.7 \mathrm{~km}$. Of the total length, to the land part belongs 158.8 $\mathrm{km}$ and to the river part $15.9 \mathrm{~km}$. It stretches from the Danube, north from Bezdan and in a slight bow it stretches towards east and northeast, near Sombor, Bajmok, Subotica, Palic and Horgos. It ends near the village Raba, where there is the states border between Serbia and Montenegro, Hungary and Romania. At its whole length the border with Hungary cuts the fruitful lowland and it is easily accessible.

Of highest importance for tourists are the following roads: Sombor -Baja, Subotica -Pecuj, Subotica-Szeged- Budapest and Kikinda-Szeged-Budapest. The highway E75 , connecting Subotica to Budapest is the most prominent in the region. There is also

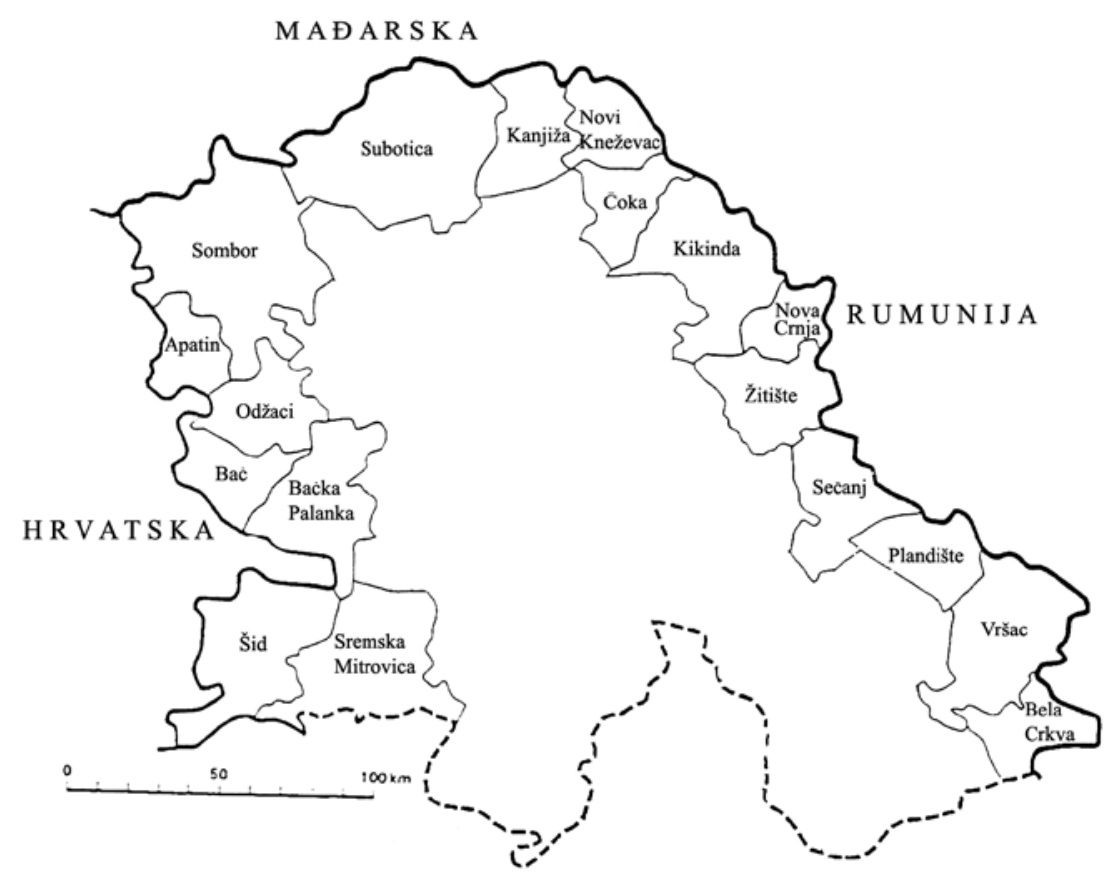

Map 1 Border region municipalities in Vojvodina 
Table 1 Settlements and areas of border region municipalities in Vojvodina

\begin{tabular}{|l|r|r|r|}
\hline \multicolumn{1}{|c|}{ Municipality } & $\begin{array}{c}\text { Number of } \\
\text { settlements }\end{array}$ & $\begin{array}{c}\text { Municipality } \\
\text { surface (km²) }\end{array}$ & Surface in Vojvodina (\%) \\
\hline Sremska Mitrovica & 26 & 762 & 3,54 \\
\hline Šid & 19 & 687 & 3,19 \\
\hline Bačka Palanka & 14 & 579 & 2,69 \\
\hline Bač & 6 & 365 & 1,70 \\
\hline Odžaci & 9 & 411 & 1,91 \\
\hline Apatin & 5 & 350 & 1,63 \\
\hline Sombor & 16 & 1178 & 5,48 \\
\hline Subotica & 19 & 1007 & 4,68 \\
\hline Kanjiža & 13 & 401 & 1,86 \\
\hline Novi Kneževac & 9 & 305 & 1,42 \\
\hline Čoka & 8 & 321 & 1,49 \\
\hline Kikinda & 10 & 782 & 3,64 \\
\hline Nova Crnja & 6 & 273 & 1,27 \\
\hline Žitište & 12 & 525 & 2,44 \\
\hline Sečanj & 11 & 523 & 2,43 \\
\hline Plandište & 14 & 383 & 1,78 \\
\hline Vršac & 24 & 800 & 3,72 \\
\hline Bela Crkva & 14 & 353 & 1,64 \\
\hline Total & $\mathbf{2 3 5}$ & $\mathbf{1 0 0 0 5}$ & $\mathbf{4 6 , 5 1}$ \\
\hline
\end{tabular}

an international railway road, connecting the Central Europe to the Balkans, that runs parallel to the highway. The Danube and Tisa, although navigable in the region, lost their previous importance due to the lack of passenger fleet (Stankovic, 1984).

Border crossings towards Hungary are: Horgos, Kelebija and Backi Breg (for road traffic), Subotica (for railway traffic), and Bezdan (for river traffic).

Annual passengers traffic in both directions outreaches 15 million, where bordercrossing Horgos is high above the rest.
From northeast and east Vojvodina borders Romania. The border runs from the village Raba, east from Kikinda, Srpska Crnja, Vrsac, and Bela Crkva to the river mouth of Nera into the Danube and further to Djerdap. The part of the border, which is in the plain and accessible, belongs to Vojvodina. Out of the total length of border towards Romania $(546.5 \mathrm{~km})$, the largest portion is on land $(257.2 \mathrm{~km})$, slightly smaller part on the Danube and Djerdap Lake $(217.9 \mathrm{~km})$, and the smallest on the rivers Karas and Nera in Banat $(71.3 \mathrm{~km})$.

Table 2 Population and population density in border region municipalites of Vojvodina.

\begin{tabular}{|c|c|c|c|c|c|}
\hline Municipality & $\begin{array}{c}\text { Number of } \\
\text { inhabitants } \\
\text { in } 1961\end{array}$ & $\begin{array}{l}\text { Inhabitants/ } \\
\mathrm{km}^{2} \text { in } 1961\end{array}$ & $\begin{array}{l}\text { Number of } \\
\text { inhabitants } \\
\text { in } 2002\end{array}$ & $\begin{array}{l}\text { Inhabitants/ } \\
\mathrm{km}^{2} \text { in } 2002\end{array}$ & $\begin{array}{c}\text { Differences } \\
\text { in number of } \\
\text { inhabitants } \\
\text { between } \\
\text { 1961. i } 2002 .\end{array}$ \\
\hline $\begin{array}{l}\text { Sremska } \\
\text { Mitrovica }\end{array}$ & 63634 & 84 & 85902 & 113 & 22268 \\
\hline Šid & 37403 & 54 & 38973 & 57 & 1570 \\
\hline Bačka Palanka & 52199 & 90 & 60966 & 105 & 8767 \\
\hline Bač & 22262 & 61 & 16268 & 45 & -5994 \\
\hline Odžaci & 42242 & 103 & 35582 & 87 & -6660 \\
\hline Apatin & 34836 & 100 & 32813 & 94 & -2023 \\
\hline Sombor & 96191 & 82 & 97263 & 83 & 1072 \\
\hline Subotica & 136782 & 136 & 148401 & 147 & 11619 \\
\hline Kanjiža & 34960 & 87 & 27510 & 69 & -7450 \\
\hline $\begin{array}{l}\text { Novi } \\
\text { Kneževac }\end{array}$ & 17831 & 58 & 12975 & 43 & -4856 \\
\hline Čoka & 19482 & 61 & 13832 & 43 & -5650 \\
\hline Kikinda & 68562 & 88 & 67002 & 86 & -1560 \\
\hline Nova Crnja & 21580 & 79 & 12705 & 47 & -8875 \\
\hline Žitište & 33514 & 64 & 20399 & 39 & -13115 \\
\hline Sečanj & 25519 & 49 & 16377 & 31 & -9142 \\
\hline Plandište & 19455 & 51 & 13377 & 35 & -6078 \\
\hline Vršac & 61284 & 77 & 54369 & 68 & -6915 \\
\hline Bela Crkva & 26276 & 74 & 20367 & 58 & -5909 \\
\hline Total & 814012 & - & 775081 & - & -38931 \\
\hline
\end{tabular}

Main traffic routes that connect Vojvodina and Romaina are: Kikinda- Timisoara, Vrsac-Timisoara, and Bela Crkva- Bazias. The road Vrsac- Timisoara is of the highest importance for the international passenger traffic because it fits into the road network towards Belgrade and Bucharest. The railroad Belgrade-Vrsac-Timisoara- Bucharest is also important. Road and river traffic is possible in the Danube sector, i.e. Djerdap sector of the border, but apart from the border-crossings on the Djerdap Lake hydropower station, others are not significant.

At the Vojvodinian part border-crossings towards Romania are: Srpska Crnja, Vatin and Kaludjerovo (road traffic), and Vrsac and Kikinda (railroad traffic). In the Djerdap sector border-crossings are Djerdap (road traffic), and Veliko Gradiste, Tekija, Kladovo and Prahovo (water traffic), but have low significance. The intensity of traffic in both directions is highest at the border-crossing Vatin. The total annual passenger traffic between Serbia and Montenegro and Romania surpasses 12 million, out of which more than one half make crossings on the Vojvodinian part of state border (Stankovic, 1986).

After the breakdown of Socialist Federal Republic of Yugoslavia, the west parts of Backa and Srem became border region towards Croatia. Contrary to various attempts of politicians, traffic connection and busier border-crossings on the Danube and in the west of Srem have not been made yet. Such status only contributes to disuniting feature of the region and disturbs the whole range of other economic activities including tourism.

\section{Borderline settlements in Vojvodina}

On the territory of Vojvodina whose are is $21,506 \mathrm{~km}^{2}$, in the year 2000 there were 467 settlements. In comparison to some other parts of Serbia it is not a large number, because there are parts of Serbia as border municipalities Zajecar, Knjazevac and Pirot, where each municipality has more than 70 settlements. Out of the total number of settlements in Vojvodina 235 or $50.3 \%$ are situated in border region, mainly in municipalities of Sremska Mitrovica (26), Vrsac (24), Sid (19), and Subotica (19), and the smallest number is recorded in municipalities of Apatin (5), Bac (6), Nova Crnja (6) and Coka (8). Out of the total area of Vojvodina, border municipalities cover $10,005 \mathrm{~km}^{2}$ or $46.51 \%$. Among border region municipalities the largest area is covered by municipalities of Sombor $\left(1,178 \mathrm{~km}^{2}\right)$, Subotica $\left(1,007 \mathrm{~km}^{2}\right)$ and Vrsac $\left(800 \mathrm{~km}^{2}\right)$, and the smallest by Nova Crnja $\left(273 \mathrm{~km}^{2}\right)$, Novi Knezevac (305 $\mathrm{km}^{2}$ ), and Coka $\left(321 \mathrm{~km}^{2}\right)$. The correlation between the number of settlements and areas of border region municipalities of Vojvodina is not directly proportional. For instance, municipality of Sremska Mitro- 
vica with 26 settlements covers the area of $762 \mathrm{~km}^{2}$, whereas municipality of Kikinda with its 10 settlements covers the area of $782 \mathrm{~km}^{2}$, which is $20 \mathrm{~km}^{2}$ more. This points out the fact the there is different density of the settlement network, which influences different economic and social processes and phenomena and also contemporary tourist traffic. An interesting fact is that municipalities of Secanj and Zitiste, which have agricultural physiognomy, have also approximately the same number of settlements and area. (Tomic, et al., 2002)

\section{Population and population density}

The whole period after the liberation in the World War II was characterized with slight depopulation of vojvodina. The number of inhabitants decreased due to different causes and it was mainly in rural settlements and in the municipalities in border region belt. After the fall apart of Former Yugoslavia when numerous refugees came from Bosnia and Herzegovina, Croatia, Kosovo and Metohija the population status changed. Mechanical population influx increased the number of inhabitants in Vojvodina. For in stance in 1961 the population of Vojvodina was 1,854,971 and in 2002 the population was $2,031,992$ which made 177,021 more inhabitants. The border region municipalities show different population statuses in that period. In the period 1961-2002, in five municipalities population increase and population density were recorded, whereas in the remaining thirteen depopulation was recorded. Generally, while the total population of Vojvodina increased for 177,021 inhabitants, the population in border region municipalites decreased for 38,931 which is more than total population in municipalites of Novi Knezevac, Nova Crnja and Plandiste today. Between the two observed years, the share of border region population in the total population decreased from $43.9 \%$ to $38.1 \%$. The present status and trends deserve special attention fo demographs, sociologists, and economists in order to find proper solutions.

Decrease in population in border region municipalites of Vojvodina has had negative effect on initiative and receptive tourism. Small number of inhabitants in municipalities of Bac, Odzaci, Apatin, Kanjiza, Novi Knezevac, Coka, Kikinda, Nova Crnaj, Zitiste, Secanj, Plandiste, Vrsac, and Bela Crkva means decreasing number of those participating in tourist travels towards tourist centres in Vojvodina, Serbia, Montenegro and abroad. At the sam etime there is a lack of labour force for different industrial branches including tourist industry. It is important to emphasise that some of the depopulated municipalities have long tourism tradition and significant tourist values, which need complementary valorization with tranzit border position and tourist values in the surroundings.

Table 3 Catering services in border region municipalities of Vojvodina in 2000

\begin{tabular}{|l|r|r|r|r|}
\hline \multicolumn{1}{|c|}{ Municipality } & $\begin{array}{c}\text { Number of catering } \\
\text { objects }\end{array}$ & $\begin{array}{c}\text { Number of } \\
\text { seats }\end{array}$ & $\begin{array}{c}\text { Number of } \\
\text { beds }\end{array}$ & $\begin{array}{c}\text { Average number of } \\
\text { beds }\end{array}$ \\
\hline Sremska Mitrovica & 9 & 1286 & 193 & 7 \\
\hline Šid & 12 & 1242 & 98 & 5 \\
\hline Bačka Palanka & 29 & 2329 & 127 & 9 \\
\hline Bač & 7 & 628 & 56 & 9 \\
\hline Odžaci & 15 & 1242 & 55 & 6 \\
\hline Apatin & 13 & 3178 & 198 & 40 \\
\hline Sombor & 112 & 6939 & 200 & 13 \\
\hline Subotica & 71 & 5787 & 584 & 31 \\
\hline Kanjiža & 4 & 1086 & 340 & 26 \\
\hline Novi Kneževac & 4 & 386 & 44 & 5 \\
\hline Čoka & 6 & 886 & - & - \\
\hline Kikinda & 8 & 2404 & 233 & 23 \\
\hline Nova Crnja & 1 & 240 & 24 & 4 \\
\hline Žitište & 3 & 378 & 70 & 6 \\
\hline Sečanj & 8 & 764 & 38 & 4 \\
\hline Plandište & 2 & 200 & 28 & 2 \\
\hline Vršac & 2 & 900 & 232 & 10 \\
\hline Bela Crkva & 7 & 1730 & 82 & 6 \\
\hline Total & $\mathbf{3 1 3}$ & $\mathbf{3 1 5 0 6}$ & $\mathbf{2 6 0 2}$ & - \\
\hline
\end{tabular}

Decrease in poulation in those municiplaities at the same time brings increase in older poulation which has negative influence on receptive and initative tourism. This results from the fact that the number of active population decreases and the number of inactive population, who lack money for tourist travels, increases.

Geographic aspects of the problem have to be dealt separately and directed from science towards practical affairs. Registry, classification, ranking and valorization of natural and antropogenous tourism development potentials have to be in concordance not only with the area, its tradition, but also with contemporary compehension of planned development, municipal, intermunicipal, regional and interregional cooperation.

\section{Material basis of tourism}

Material basis of tourism consists of catering and accommodation facilities, traffic lines and traffic devices. As well as in other places, in borderline region of Vojvodina they are not built exclusively for tourism purposes, but for domicile population and its economy. Thus, the construction of the material basis of tourism is the direct result of economic development in the surroundings, but also the result of tradition, tourist offer organization at domestic and foreign tourist market.

Tourism has to be developed complementary with other industrial branches in border region, because it is a low-accumulative activity, which is unable to provide significant accumulation of funds for wider reproduction. In borderline municipalities of Vojvodina, it has to be coordinated with agriculture, because tourists are also consumers of agricultural products. Furthermore, certain tourist manifestations (Duzijansa,
Harvest Festival in Subotica, Grape gathering in Vrsac and Fish Festival in Apatin) are tightly connected with agriculture. Nowadays, the world insists on pointing out local tourism features, amenities and geographical origin of products for tourist market, which may have high significance for border region municipalities. (Stankovic, Obradovic, 2002).

The total number of catering objects in Vojvodina in 2000 was 624 . Out of that number in border region there were 313 objects or $50.15 \%$. The number of catering seats was 64,322 , out of which 31,506 or $49 \%$ were in border region. In 2000 Vojvodina had 7490 beds for tourists. Out of that number 2,602 beds or $34.7 \%$ were in border region. Those objects were mainly states property, which are still dominant over the private catering objects.

Among border region municipalities in Vojvodina, the largest number of catering objects belongs to Subotica and Sombor. On the contrary, Vrsac and Plandiste have only two states catering objects, and Nova Crnja only one. The similar situation is with seats and beds as important features of tourist offer. The largest number of beds is in Subotica, mainly near the Palic Lake. Then follows Kanjiza, where spa tourism is flourishing and new objects were built next to old ones. These are all consequences of small territory, intensive agricultural structure of the area, lack of confirmed tourist values and appropriate tradition. However, the positive contribution to tourism in border region has been added by large number of new private objects, most of which primarily serve to fulfill the needs of local population.

It seems that for the further development of tourism in border region in Vojvodina it is not necessary to build new ca- 
Table 4 The index of tourism in border region municipalities of Vojvodina.

\begin{tabular}{|c|c|c|c|c|c|c|}
\hline \multirow{2}{*}{ Municipality } & \multicolumn{2}{|c|}{ Tourists } & \multirow{2}{*}{ Difference } & \multicolumn{2}{|c|}{ Overnights } & \multirow{2}{*}{ Difference } \\
\hline & 1990. & 2000. & & 1990. & 2000. & \\
\hline 1. Sremska Mitrovica & 17929 & 6119 & -11810 & 35805 & 13672 & -22133 \\
\hline 2. Šid & 13832 & 16650 & 2818 & 13832 & 17433 & 3601 \\
\hline 3. Bačka Palanka & 8542 & 1957 & -6585 & 15530 & 3435 & -12095 \\
\hline 4. Bač & 1226 & 417 & -809 & 2937 & 1086 & -1851 \\
\hline 5. Odžaci & 3291 & 1137 & -2154 & 5962 & 2658 & -3304 \\
\hline 6. Apatin & 9003 & 5269 & -3734 & 51834 & 58675 & 6841 \\
\hline 7. Sombor & 15355 & 8920 & -6435 & 29366 & 18659 & -10707 \\
\hline 8. Subotica & 76231 & 27376 & -48855 & 116890 & 53578 & -63312 \\
\hline 9. Kanjiža & 11708 & 10848 & -860 & 78823 & 103899 & 25076 \\
\hline 10. Novi Kneževac & 577 & 929 & 352 & 1081 & 2006 & 925 \\
\hline 11. Čoka & - & - & - & - & - & - \\
\hline 12. Kikinda & 18730 & 9879 & -8851 & 40320 & 33941 & -6379 \\
\hline 13. Nova Crnja & 1081 & 55 & -1026 & 2181 & 55 & -2126 \\
\hline 14. Žitište & 2284 & 2061 & -223 & 5341 & 7349 & 2008 \\
\hline 15. Sečanj & 2149 & 498 & -1651 & 5007 & 7349 & 2342 \\
\hline 16. Plandište & 1441 & 594 & -847 & 2992 & 3304 & 312 \\
\hline 17. Vršac & 12120 & 12298 & 178 & 23762 & 44322 & 20560 \\
\hline 18. Bela Crkva & 6602 & 1142 & -5460 & 18152 & 2460 & -15692 \\
\hline Total & 202101 & 106149 & - & 449815 & 367586 & \\
\hline
\end{tabular}

tering and accommodation objects, but to make better use of the existing objects, primarily by attracting more domestic and foreign tourists. To realize the goal, first contractive zones of natural and antropogenous tourist values in every municipality should be clearly defined, and then the directions of cooperation in the region should be defined as well as the proper position of those municipalities in tourism of Vojvodina and Serbia. It is achieved through systematic research in the field of tourism and geography in order to estimate the present status and prospects for development. All tendencies should be directed towards elements of joining and inter relations of tourist values, time, area and events.

\section{Tourists and overnight stays}

The most relevant index of conditions in tourism in general is the number of tourists and the number of overnight stays.
In 1990 in Vojvodina there were 514,263 registered tourists, out of which 202,101 or $39.3 \%$ were registered in border region municipalities. In the same year, there were 1,129,049 overnight stays, out of which 449,815 or $39.8 \%$ were in border region municipalities.

Those statistical data clearly show not only stagnation, but also decrease in tourist traffic. It is the consequence of the events which followed the breakdown of the SFRY, such as creation of new borders, stagnation of economy and low standard of living. And etc. Also, that was the beginning of the owner transformation period of tourist objects and loss of almost total foreign tourist market. Positive business in tourism and catering services was recorded in municipalities of Vrsac and Kanjiza, whereas in Plandiste, Secanj, Novi Knezevac, Apatin and Sid were no significant changes. Comparison of the municipalities would indicate the whole range of specific features. Certain municipalities have developed tourist offer and satisfactory number of tourists and overnight stays (Kanjiza, Subotica, Apatin, Vrsac), on the other hand there are municipalities with humble potential, underdeveloped offer, weak organization and small tourist traffic and overnight stays (Nova Crnja, Bac, Zitiste), or even those without tourist traffic at all (Coka).

\section{References}

1. Romelić, J., et al., (2002): Kulturna dobra u turističkoj ponudi Vojvodine, Departman za geografiju, turizam i hotelijerstvo, PMF, Novi Sad.

2. Stanković, S., (1984): Promet putnika na granicama Jugoslavije, Posebna izdanja Srpskog geografskog društva, knjiga 60, Beograd.

3. Stanković, S., (1986): Promet putnika na granici prema Rumuniji, Glasnik Srpskog geografskog društva, LXVI/2, Beograd.

4. Tomić, P., et al., (2002): Vojvodina, naučno-popularna monografija, Departman za geografiju, turizam i hotelijerstvo, PMF, Novi Sad.

5. Opštine u Srbiji 2001, Republički zavod za informatiku i statistiku, Beograd, 2002.

6. Popis '91 - stanovništvo, knjiga 9 , Savezni zavod za statistiku, Beograd, 1995.

7. Popis stanovništva, domaćinstava i stanova u 2002, knjiga 2, Republički zavod za statistiku, Beograd, 2003.

8. Stanković, S., Obradović, D., (2002): Materijalna baza turizma u pograničnim opštinama Srbije prema Mađarskoj, Rumuniji i Bugarskoj, Zbornik radova „Problemi revitalizacije pograničnih krajeva Jugoslavije i Republike Srpske", Geografski fakultet Univerziteta u Beogradu, Beograd.

9. Opštine u Republici Srbiji 1991, Republički zavod za statistiku, Beograd, 1992. 